\title{
Algicidal effect of the bacterium Alcaligenes denitrificans on Microcystis spp.
}

\author{
Pathmalal M. Manage ${ }^{1, *}$, Zen'ichiro Kawabata $^{2}$, Shin-ichi Nakano ${ }^{3}$ \\ ${ }^{1}$ Department of Life Environment Conservation Sciences, The United Graduate School of Agricultural Sciences, \\ Ehime University, Tarumi 3-5-7, Matsuyama 790-8566, Ehime, Japan \\ ${ }^{2}$ Center for Ecological Research, Kyoto University, Kamitanakami Hirano-cho 509-3, Otsu 520-2113, Japan \\ ${ }^{3}$ Center for Marine Environmental Studies (CMES), Ehime University, 3 Bunkyo-cho, Matsuyama 790-8577, Ehime, Japan
}

\begin{abstract}
A freshwater gliding bacterium, Alcaligenes denitrificans, was isolated from a hypereutrophic pond in Japan. This bacterium caused cell lysis and death of some cyanobacterial species, but showed no algicidal effects on the species of chlorophyceae tested. Microcystis aeruginosa, M. viridis and $M$. wesenbergii were susceptible to the bacterial attack and the growth-inhibiting effect of the bacterium was significant on $M$. aeruginosa, particularly when the alga was in the exponential

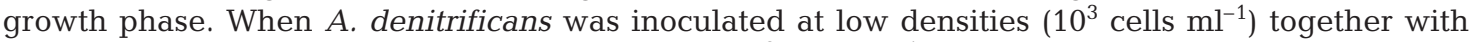
Microcystis species, the bacterium proliferated to $10^{8} \mathrm{cells} \mathrm{ml}^{-1}$ and caused algal cell lysis. M. aeruginosa died when $A$. denitrificans was added to the algal culture but not when only the filtrate from the bacterial culture was added. This suggests that extracellular products are not inhibitory to $M$. aeruginosa and that only direct contact between $A$. denitrificans and $M$. aeruginosa was lethal. Thus, we suggest that $A$. denitrificans plays an important role in influencing the growth of Microcystis spp. and contributes to the death of Microcystis spp. in freshwater environments.
\end{abstract}

KEY WORDS: Algicidal effect · Alcaligenes denitrificans $\cdot$ Microcystis

Resale or republication not permitted without written consent of the publisher

\section{INTRODUCTION}

It is now widely accepted that bacteria can determine the physiological state of microalgae. Some bacteria selectively promote bloom formation (Furuki \& Kobayashi 1991), while others have algicidal effects and are involved in the termination and decomposition of algal blooms (Fukami et al. 1992). However, the importance of inhibitory bacteria in regulating populations of different algal species has not yet been fully investigated (Fukami et al. 1996).

Gliding bacteria such as Mухососсus (Burnham et al. 1981, 1984), Lysobacter (Daft \& Stewart, 1971, Mitsutani et al. 1987), Flexibacter (Gromov et al. 1972), Myxobacter (Shilo 1970, Yamamoto \& Suzuki 1990), Alcaligenes spp., Flavobacterium spp., Pseudomonas spp. (Yamamoto et al. 1993) and Cytophaga (Stewart \&

*E-mail: path@agr.ehime-u.ac.jp
Brown 1969, Yamamoto et al. 1993) all have the ability to lyse blue green algae in freshwater environments. Daft \& Stewart (1971) recorded that isolated Cytophaga strains have the ability to lyse Microcystis spp. and Yamamoto \& Suzuki (1990) reported the lysis effect of Myxococcus fulvus (S-1-8) on Microcystis aeruginosa, $M$. wesenbergii and $M$. viridis. Yamamoto et al. (1993) found that some strains of Alcaligenes also lysed Microcystis spp., and their studies reported isolation, morphology and the host range of Alcaligenes. Thus, the amount of detailed information about the relationship between cyanobacteria and their algicidal bacteria is still limited. We have previously observed the seasonal occurrence of $M$. aeruginosa and of algicidal bacteria which lyse this cyanobacterium in a hypereutrophic pond and suggested the use of algicidal bacteria to suppress blooms of $M$. aeruginosa. While monitoring that situation, we isolated the bacterium Alcaligenes denitrificans. In this paper we 
describe some properties of $A$. denitrificans and its growth-inhibiting or algicidal effects on the growth of $M$. aeruginosa, $M$. wesenbergii and $M$. viridis. We also discuss the effect of the bacterium on different growth stages of the 3 Microcystis spp., the minimum bacterial density required for rapid lysis, the range of potential target organisms for this bacterium, and its algicidal activity in culture filtrate. As far as we are aware, this is the first report of the algicidal effect of $A$. denitrificans on Microcystis spp.

\section{MATERIALS AND METHODS}

Organisms. Bacterial strains thought to kill Microcystis aeruginosa were isolated from surface water samples collected from the hypereutrophic Furuike Pond in Sancho, Matsuyama City, Ehime Prefecture, Japan, in August 1998. A slightly modified version of the plaque method (Safferman \& Morris 1964) was used to isolate the algicidal bacteria. Algal lawns were prepared on MA agar medium (Manage et al. 1999) in petri dishes, using an axenic culture of $M$. aeruginosa (NIES-298). They were inoculated with $1 \mathrm{ml}$ of water sample filtered through a sterilized $0.8 \mu \mathrm{m}$ Nuclepore membrane filter (Millipore Co.). The $M$. aeruginosa lawns thus treated were incubated at $25^{\circ} \mathrm{C}$, under a light intensity of (48.8 to 58.6) $\mu \mathrm{E} \mathrm{m}^{-2} \mathrm{~s}^{-1}$ with a $12 \mathrm{~h}$ light:12 h dark photo-cycle for 10 to $12 \mathrm{~d}$, and bacteria were then picked out from a clear plaque, where the $M$. aeruginosa had died out. These bacteria were cultured in modified casitone medium and incubated overnight under dark conditions at $34^{\circ} \mathrm{C}$. Each bacterial culture was diluted and $1 \mathrm{ml}$ from each dilution was mixed with $1.5 \%$ of modified casitone molten agar medium ( 38 to $40^{\circ} \mathrm{C}, 20$ to $25 \mathrm{ml}$ ) and poured onto sterilized petri dishes. The treated petri dishes were incubated in the dark at $34^{\circ} \mathrm{C}$ for $3 \mathrm{~d}$. Bacteria were re-isolated repeating this spread plate method (Adams 1959, Shilo 1970, Yamamoto \& Suzuki 1990). After purification, each isolated strain of bacteria, in the logarithmic growth phase, was inoculated into an axenic culture of $M$. aeruginosa which was previously cultured in MA medium (Ichimura 1978). In this way, 1 strain with a significant inhibitory effect on $M$. aeruginosa was successfully isolated. This bacterium was identified as Alcaligenes denitrificans (PROB $94 \%$ TYPE GN-OXI ${ }^{+}$) using a Biolog System (Microlog ${ }^{\mathrm{TM}}$ Microbial Identification System, Release 4.0, 1990. Biolog, Inc., Hayward, CA, USA). It was maintained on modified casitone medium containing $0.1 \mathrm{~g}$ yeast extract, $1 \mathrm{~g}$ Difco casitone, $0.1 \mathrm{~g} \mathrm{MgSO} 47 \mathrm{H} 2 \mathrm{O}$ and $1.5 \mathrm{~g}$ agar in $100 \mathrm{ml}$ of distilled water (Yamamoto \& Suzuki 1990).

Algicidal effects. The algicidal effects of Alcaligenes denitrificans on the growth of Microcystis aeruginosa
(NIE 298), M. wesenbergii (NIE 104) and M. viridis (NIE 102) in the lag, exponential and stationary growth phases were investigated. Axenic cultures of these algae were provided by the National Institute of Environmental Studies, Japan. Algal cultures of each species, in MA medium, were appropriately diluted (2 to $6 \times 10^{6}$ cells $\mathrm{ml}^{-1}$ ) with the same medium and $95 \mathrm{ml}$ aliquots were inoculated into duplicate $250 \mathrm{ml}$ Erlenmeyer flasks. The bacterium A. denitrificans was incubated in liquid casitone medium at $34^{\circ} \mathrm{C}$ overnight. When the cell density reached 1 to $2 \times 10^{8}$ cells $\mathrm{ml}^{-1}$, the culture was then centrifuged $(3500 \mathrm{rpm}[2200 \times g] 10 \mathrm{~min})$, washed twice with sterilized MA medium and $5 \mathrm{ml}$ aliquots were inoculated into the algal cultures at final concentrations of 1 to $2 \times 10^{4}$ cells ml ${ }^{-1}$. Duplicate control cultures were prepared by adding $5 \mathrm{ml}$ of MA medium to $95 \mathrm{ml}$ of the algal culture. The flasks were incubated at $25^{\circ} \mathrm{C}$ under a light intensity of 48.8 to $58.6 \mu \mathrm{E} \mathrm{m}^{-2} \mathrm{~s}^{-1}$ with a $12 \mathrm{~h}$ light:12 $\mathrm{h}$ dark photo-cycle. The cell density of the 3 Microcystis spp. was determined using a haemocytometer under a microscope. The decrease rate $(h)$ of the cell densities of the $3 \mathrm{Mi}$ crocystis spp. were calculated as $h=\ln \left(C / C_{0}\right) / t$, where $C_{0}$ and $C$ are the Microcystis cell densities at the beginning and at the end of the time interval $t$, respectively.

Bacterial cell density and algicidal effect. A cell suspension of Alcaligenes denitrificans in the logarithmic growth phase was diluted in MA medium, and $90 \mathrm{ml}$ of the bacterial culture, at initial concentrations of $1.5 \times$ $10^{3}, 1.5 \times 10^{4}, 1.5 \times 10^{5}$ and $1.5 \times 10^{6}$ cells ml ${ }^{-1}$ were prepared. We inoculated $10 \mathrm{ml}$ of exponentially growing cultures of each Microcystis spp. into these bacterial cultures at a final concentration of $2.0 \times 10^{6} \mathrm{cells} \mathrm{ml}^{-1}$. Cultures without the bacterium served as controls. Incubation conditions were the same as described above for algae. The cell densities of Microcystis spp. and the bacterium were determined in the haemocytometer and by the spread plate method (Adams 1959), respectively.

Algicidal range of Alcaligenes denitrificans. The algicidal range of the bacterium Alcaligenes denitrificans was examined by liquid culture and algal lawn assay with 18 species of freshwater phytoplankton. There were 9 species of Cyanophyceae and 9 species of Chlorophyceae (see Table 3 ). The algal cultures were all axenic except for A. spiroides, A. affinis, Aphanizomenon flosaquae, Oscillatoria limnetica and Anabaenopsis curcularis. Each algal species was appropriately diluted ( 2 to $5 \times 10^{5}$ cells $\mathrm{ml}^{-1}$ ) with the culture medium and $9 \mathrm{ml}$ aliquots were inoculated into duplicate test tubes. The bacterium was grown in the liquid casitone medium described above, and an overnight culture (incubation at $34^{\circ} \mathrm{C}$ ) of 1 to $2 \times 10^{8} \mathrm{cells} \mathrm{ml}^{-1}$ was diluted, centrifuged and washed twice with sterilized culture solutions. Aliquots of $1 \mathrm{ml}$ were added to the tubes of algae at final 
concentrations of 1 to $2 \times 10^{4}$ cells ml ${ }^{-1}$, and the test tubes were incubated at $25^{\circ} \mathrm{C}$ under a light intensity of 48.8 to $58.6 \mu \mathrm{E} \mathrm{m}^{-2} \mathrm{~s}^{-1}$ with a $12 \mathrm{~h}$ light:12 h dark photo-cycle. Enumeration of algal cell densities in treated and control tubes was carried out using a haemocytometer and the significant decreases of cell densities in the treated tubes compared to controls were considered to indicate susceptibility to bacterial attack. For the algal lawn assay, the algae were considered to be susceptible when a distinctly clear zone of algal lysis occurred with the addition of the bacterium $A$. denitrificans.

Algicidal activity in culture filtrate. The algicidal effect of dissolved chemical substances derived from Alcaligenes denitrificans was examined. We inoculated $2 \mathrm{ml}$ of the bacterium culture, in its logarithmic growth phase, into $300 \mathrm{ml}$ of Microcystis aeruginosa culture $\left(2.0 \times 10^{5}\right.$ cells ml $\left.^{-1}\right)$ in a $500 \mathrm{ml}$ Erlenmeyer flask. After $4 \mathrm{~d}$ of incubation the bacterium reached a density of $6.2 \times 10^{8}$ cells $\mathrm{ml}^{-1}$ while the cell density of $M$. aeruginosa decreased to $3.6 \times$ $10^{3}$ cells $\mathrm{ml}^{-1}$. The culture was then filtered through a sterilized $0.1 \mu \mathrm{m} \mathrm{Nu}$ clepore filter, and the filtrate was diluted to final concentrations of 10, 50 and $90 \%$ with autoclaved filtrate, in duplicate, and then inoculated with $M$. aeruginosa $\left(2.0 \times 10^{5}\right.$ cells $\left.\mathrm{ml}^{-1}\right)$. The cell densities of $M$. aeruginosa were determined as described above.

\section{RESULTS}

The bacterium isolated from the pond water was identified as Alcaligenes denitrificans and showed a significant growth-inhibiting effect on 3 species of Microcystis in different growth phases (Fig. 1). When Microcystis spp. was in the exponential growth phase, the effect was very pronounced. $M$. aeruginosa was particularly susceptible when $A$. denitrificans was added to the exponential or stationary growth phases and the rate of decrease in the cyanobacterium was significant (Table 1). However, the algicidal effect was not so significant when it was added to the lag growth phase of $M$. aeruginosa, and after an initial slight decrease the algal cell density increased again (Fig. 1a). With
$M$. viridis, the effects of the bacterium were very similar in all 3 growth phases, but those rates were low when compared with the rate of decrease in $M$. aeruginosa (Table 1, Fig. 1b). In the case of $M$. wesenbergii, the algicidal effect was less than that on the other 2 species and the rates of decrease in each growth phase were lower still (Table 1, Fig. 1c).

Thus, in this study there appeared to be remarkable decreases in cell densities of Microcystis aeruginosa at any bacterial inoculum size, after the bacteria cell den-
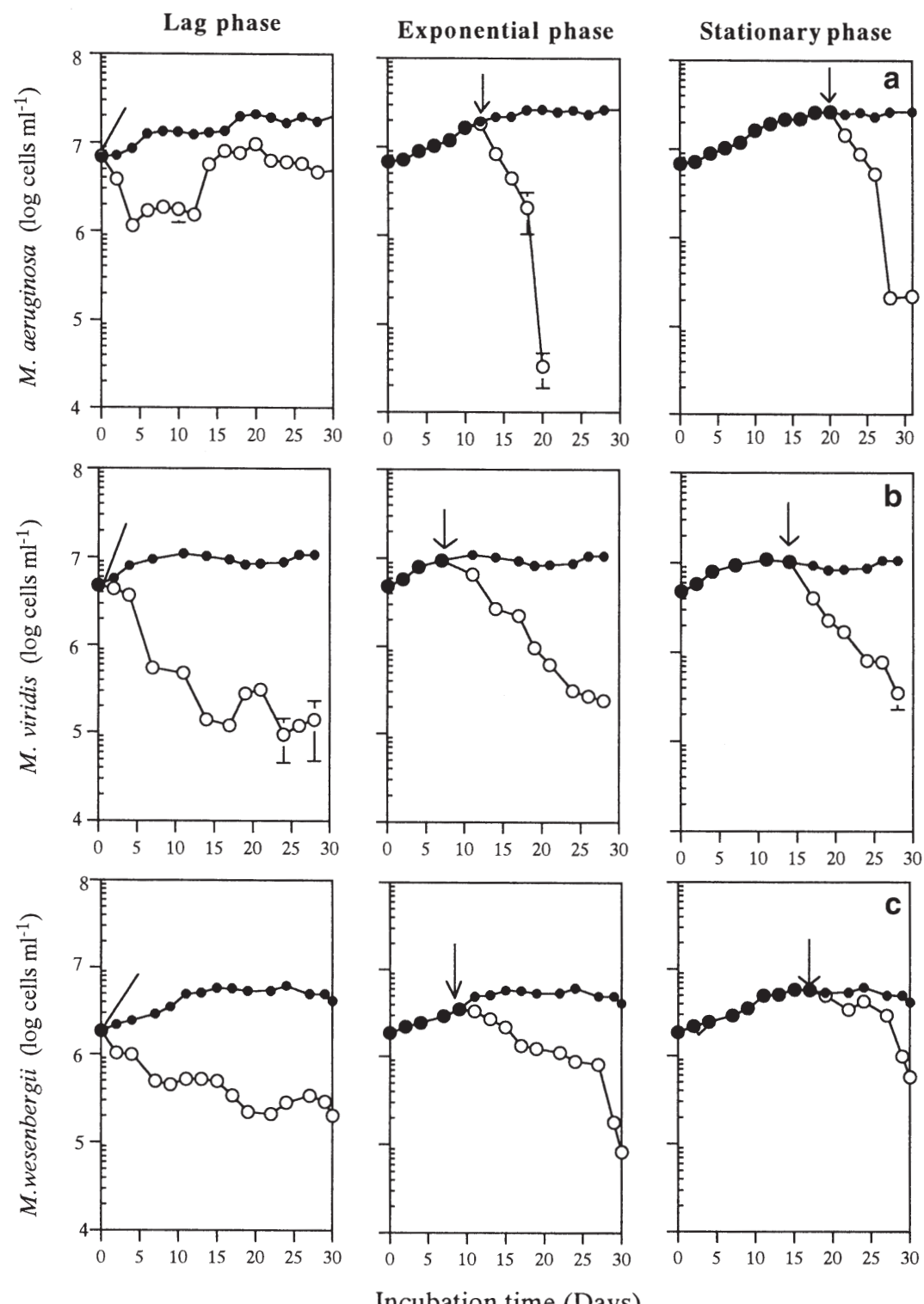

Fig. 1. Effect of the bacterium Alcaligenes denitrificans on the growth of (a) Microcystis aeruginosa, (b) M. viridis, and (c) M. wesenbergii in different stages of growth (O). Control without bacterium inoculation ( $(\bullet)$ is also shown. The time of bacterium inoculation is indicated by an arrow. When error bars are not shown, standard deviation was less than the width of the symbols 
Table 1. Microcystis spp. Rate of decrease in cell densities in the lag, exponential and stationary growth phases (given as mean values of duplicates)

\begin{tabular}{|c|c|c|c|}
\hline Growth phase & $\begin{array}{c}\text { Days after bacterium } \\
\text { inoculation }\end{array}$ & $\begin{array}{l}\text { Decrease } \\
\text { rate }\left(d^{-1}\right)\end{array}$ & $\pm \mathrm{SD}$ \\
\hline \multicolumn{4}{|l|}{ M. aeruginosa } \\
\hline Lag & $\mathrm{ND}^{\mathrm{a}}$ & $\mathrm{ND}^{\mathrm{a}}$ & $\mathrm{ND}^{\mathrm{a}}$ \\
\hline Exponential & 10 & 0.621 & 0.030 \\
\hline Stationary & 13 & 0.352 & 0.020 \\
\hline \multicolumn{4}{|l|}{ M. viridis } \\
\hline Lag & 17 & 0.216 & 0.009 \\
\hline Exponential & 17 & 0.201 & 0.006 \\
\hline Stationary & 12 & 0.215 & 0.008 \\
\hline \multicolumn{4}{|l|}{ M. wesenbergii } \\
\hline Lag & 19 & 0.112 & 0.007 \\
\hline Exponential & 18 & 0.081 & 0.019 \\
\hline Stationary & 10 & 0.067 & 0.005 \\
\hline
\end{tabular}

sity reached the order $10^{8}$ cells $\mathrm{ml}^{-1}$ (Fig. 2a). The cell densities of $M$. aeruginosa decreased from about $10^{6}$ to $10^{4}$ cells ml $\mathrm{ml}^{-1}$ in $4 \mathrm{~d}$, and continued to decline steeply, except where the initial inoculum concentration of the bacterium was $10^{3}$ cells $\mathrm{ml}^{-1}$. $M$. aeruginosa was undetectable after $10 \mathrm{~d}$ of incubation, coincident with a decrease in the cell density of Alcaligenes denitrificans (Fig. 2b). The cell density of $M$. viridis also declined at all bacterial inoculum concentrations, although the rates of decrease were lower (Table. 2), and considerable densities of $M$. viridis cells were detected with each bacterial inoculum even after $12 \mathrm{~d}$ of incubation (Fig. 2c). In the case of M. wesenbergii, after $2 \mathrm{~d}$ of incubation the concentrations of each bacterial inoculum increased up to the order of $10^{7}$ cells ml ${ }^{-1}$ (Fig. 2f). The cell densities of $M$. wesenbergii decreased slightly and remained in the order of $10^{5}$ cells ml $\mathrm{m}^{-1}$ until Day 9 , when they decreased more steeply (Fig. 2e) and the bacterial cell density increased to $10^{8}$ cells $\mathrm{ml}^{-1}$. Thus, in this study there was no rapid death of $M$. viridis and $M$. wesenbergii with any inoculum concentration, even after the bacterial cell density reached $10^{8}$ cells ml $\mathrm{ml}^{-1}$ (Fig. 2).

All the Cyanophyceae tested were susceptible to bacterial attack. When the bacterium was placed on a algal lawn of Microcystis spp., the test culture produced a gradient of lysis. Under the microscope, we found disintegrating algal cells surrounded by the bacterium, in the center of the lytic zone, where the algal cells were completely destroyed. In an infected liquid culture of algae, we observed gradual decolorization and disintegration of the cells. None of the strains of Chlorophyceae tested were susceptible to bacterial attack, although growth of Treubaria triappendiculata and Tetraedron incus was suppressed (Table 3).
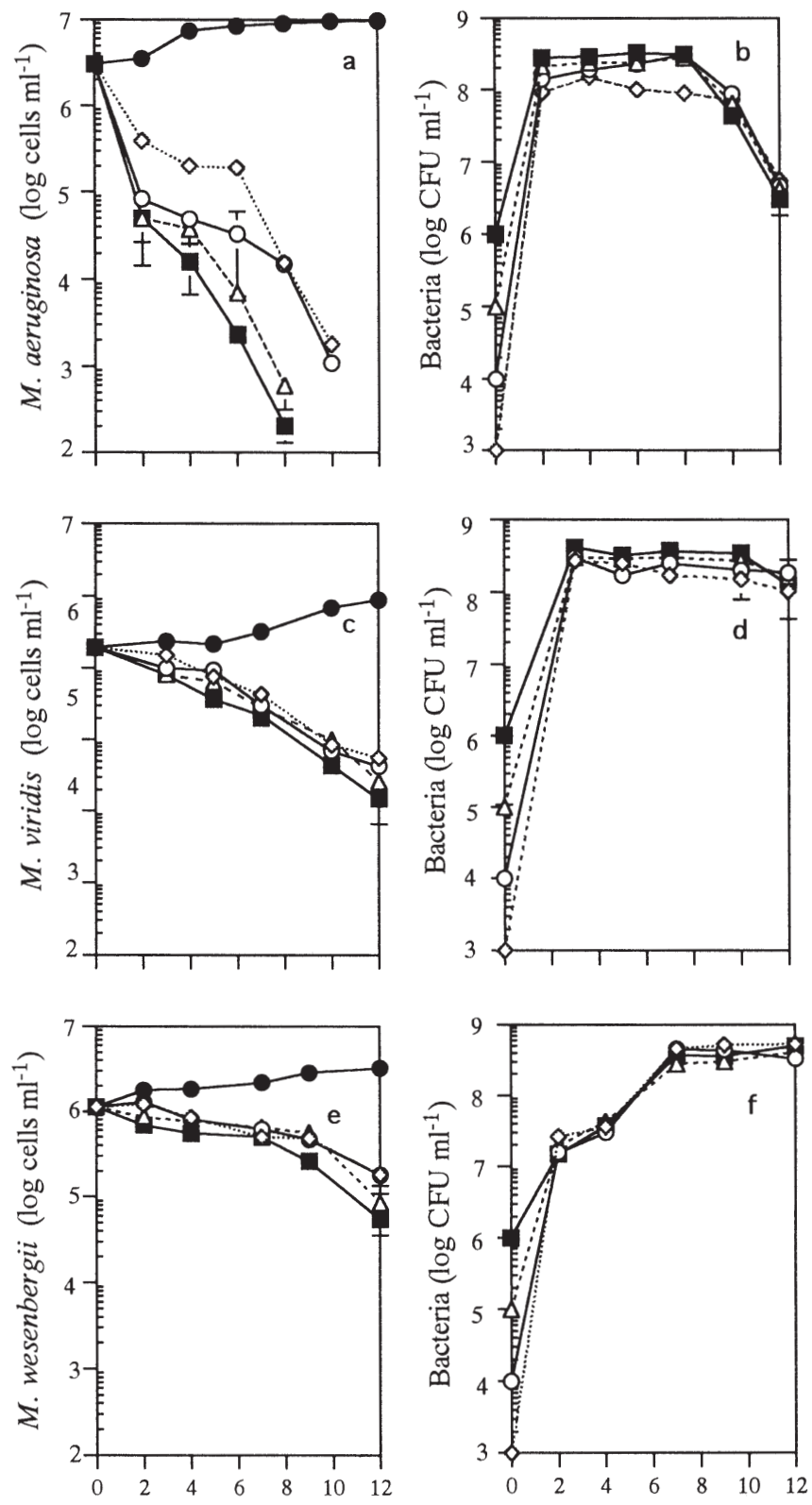

Incubation time (Days)

Fig. 2. Changes in cell densities of (a) Microcystis aeruginosa, (c) $M$. viridis, (e) $M$. wesenbergii and (b, $\mathrm{d}$, f) the bacterium Alcaligenes denitrificans after inoculation with different initial densities $(\bullet$, control without bacterial inoculation cells $\mathrm{ml}^{-1} ; \diamond, 10^{3}$ bacteria CFU ml ${ }^{-1} ; 0,10^{4}$ bacteria CFU ml ${ }^{-1} ; \Delta$, $10^{5}$ bacteria $\mathrm{CFU} \mathrm{ml}{ }^{-1} ; \mathbf{\square}, 10^{6}$ bacteria $\mathrm{CFU} \mathrm{ml}{ }^{-1}$ ). When error bars are not shown, standard deviation was less than the width of the symbols. CFU: colony forming units

The 10 and $50 \%$ diluted culture filtrates, in which Microcystis aeruginosa had been killed by the bacterium Alcaligenes denitrificans, had no inhibitory effect on $M$. aeruginosa. Moreover, $M$. aeruginosa even grew in the presence of $90 \%$ culture filtrate without any inhibitory effect being detected (Fig. 3). 
Table 2. Microcystis spp. Rate of decrease in cell densities (2 d after the bacterium inoculation) in each bacterium inoculum (given as mean values of duplicates)

\begin{tabular}{llll}
\multirow{2}{*}{$\begin{array}{l}\text { Bacterium } \\
\text { inoculum size } \\
\text { (cells ml }{ }^{-1} \text { ) }\end{array}$} & M. aeruginosa & $M$. viridis & $M$. wesenbergii \\
\cline { 2 - 4 } & & & \\
\hline $10^{3}$ & $1.02 \pm 0.06$ & $0.08 \pm 0.04$ & $0.03 \pm 0.006$ \\
$10^{4}$ & $1.70 \pm 0.66$ & $0.22 \pm 0.02$ & $0.06 \pm 0.030$ \\
$10^{5}$ & $2.05 \pm 0.15$ & $0.28 \pm 0.08$ & $0.13 \pm 0.025$ \\
$10^{6}$ & $2.05 \pm 0.24$ & $0.28 \pm 0.09$ & $0.24 \pm 0.046$
\end{tabular}

Table 3. Alcaligenes denitrificans. Host susceptibility of the bacterium. +: susceptible; \pm : growth affected $;$-: non-susceptible

\begin{tabular}{|lc|}
\hline Species & Susceptibility \\
\hline Microcystisa eruginosa (NIES298) & + \\
Microcystis viridis (NIES102) & + \\
Microcystis wesenbergii (NIES104) & + \\
Anabaena flos-aquae (NIES73) & + \\
Anabaena spiroides (NIES77) & + \\
Aphanizomenon flos-aquae (NIES81) & + \\
Anabaena affinis (NIES40) & + \\
Anabaenopsis circularis (NIES21) & + \\
Oscillatoria limnetica (NIES36) & + \\
Treubaria triappendiuculata (NIE394) & \pm \\
Tetraedron incus (NIES392) & \pm \\
Cateria inversa (NIES422) & - \\
Chlamydomonas neglecta (NIES439) & - \\
Pediastrum duplex (NIES210) & - \\
Scenedesmus acutus (NIES94) & - \\
Closterium acerosum (NIES124) & - \\
Micractinium pusillum (NIES151) & - \\
Staurastrum paradoxum (NIES528) & - \\
& \\
\hline
\end{tabular}

\section{DISCUSSION}

Blooms of freshwater cyanobacteria, particularly of the genus Microcystis, are a serious indication of freshwater eutrophication and have harmful effects on lake ecology, livestock and, potentially, on human beings (Carmichael et al. 1985, Song et al. 1998). The most direct form of control involves the removal of high nutrient load (Horne \& Goldman 1994) and application of chemical algicides, but the latter is potentially damaging to the environment, and there is a risk of accumulation of harmful concentrations in bottom sediments (Mason 1996). An alternative approach to the direct elimination of nuisance algae involves the application of biological control agents that have the ability to destroy or limit the growth of the target algae (Sigee et al. 1999).

Alcaligenes denitrificans is aerobic and is capable of anaerobic growth by denitrification (Holt et al. 1994). The decolorization and disintegration of Microcystis
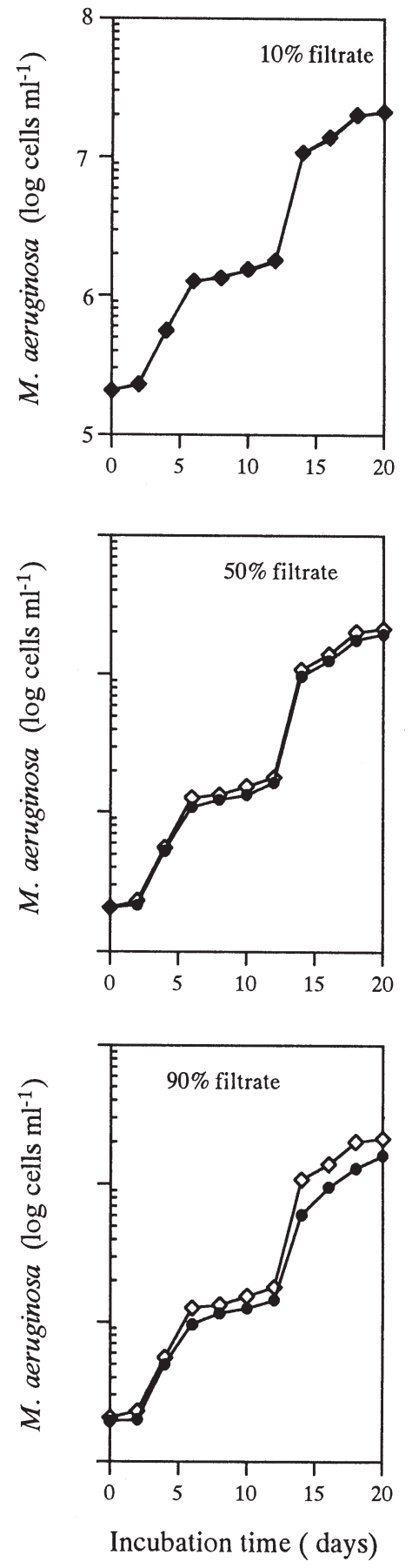

Fig. 3. Effect of filtrate from the culture in which Microcystis aeruginosa was killed by the bacterium Alcaligenes denitrificans $(\diamond$, autoclaved culture filtrate as control; $\bullet$, with culture filtrate). When error bars are not shown, standard deviation was less than the width of the symbols

spp. cells after being attacked by the bacterium indicate rapid inhibition of the metabolic activity of the algae. A. denitrificans is a Gram-negative rod which moves by slow gliding, has non-pigmented colonies, 
does not use carbohydrates on nutrient agar and has an optimum temperature of 20 to $37^{\circ} \mathrm{C}$. Thus, most of the characteristic features of $A$. denitrificans are similar to those of other freshwater algicidal bacteria which have been isolated so far (Daft \& Stewart 1971, Burnham et al. 1981, 1984, Mitsutani et al. 1987).

The bacterium Alcaligenes denitrificans had an algicidal effect on the 3 Microcystis species tested (Fig. 1). We detected a significant growth-inhibiting effect on $M$. aeruginosa when in the exponential and stationary growth phases (Fig. 1, Table 1). In contrast, the decrease in cell density in $M$. viridis and $M$. wesenbergii was much less significant, even when they were in the exponential and stationary growth phases. Thus, we suggest that the algicidal effect of the bacterium is stronger for M. aeruginosa than for these other Microcystis spp. The algicidal effect of the bacterium on $M$. aeruginosa was less significant when it was added to the lag growth phase, and this may suggest that the physiological status of the algae is important for bacterial attack.

The freshwater gliding bacterium Myхососcus fulvus (BGO2) could not reduce the densities of the cyanobacteria Nostoc muscorum and Phormidium luridum when its initial density was lower than $5 \times 10^{6}$ cells ml ${ }^{-1}$ (Fraleigh \& Burnham 1988), and at least $10^{6}$ cells $\mathrm{ml}^{-1}$ of the bacterium were required to cause significant algal cell lysis (Fraleigh \& Burnham 1988). Fallon \& Brock (1979) suggested that a decrease in natural algal abundance due to lysis was negligible when lytic bacteria populations were $<10^{3}$ cells $\mathrm{ml}^{-1}$. In the present study, even when Alcaligenes denitrificans was inoculated at low densities $\left(10^{3}\right.$ cells $\left.\mathrm{ml}^{-1}\right)$ it proliferated to $10^{8}$ cells ml ${ }^{-1}$ and caused algal cell lysis in the 3 Microcystis spp. M. aeruginosa was undetectable $10 \mathrm{~d}$ after incubation, while considerable densities of $M$. viridis and $M$. wesenbergii remained with all $A$. denitrificans inoculum concentrations, even after $12 \mathrm{~d}$ of incubation. Thus, we suggest that the algicidal effect of $A$. denitrificans is more lethal on $M$. aeruginosa than on $M$. viridis and $M$. wesenbergii.

Rapid lysis of several species of blue-green algae by an isolated Myxobacter strain (Shilo 1970), isolated Cytophage strains (Daft \& Stewart 1971), and an isolated Flavobacterium (Yamamoto \& Suzuki 1990) have been recorded. In the present study, we also detected that all the tested Cyanophyceae were susceptible to bacterial attack, suggesting that $A$. denitrificans has a wide host range (Table 3 ).

Two particular kills of phytoplankton by bacteria have been studied in detail with regard to contact (Burnham et al. 1984) and production of inhibitory substances (Day \& Withers 1985). Burnham et al. (1981) reported that the cyanobacterium Phormidium luridum was lysed by Myxососcus xanthus through direct con- tact. In the present study, death was detected when Alcaligenes denitrificans was added to the algal culture but not when only the culture filtrate was added (Figs. 1 \& 3). This indicates that $A$. denitrificans did not release extracellular products inhibitory to Microcystis aeruginosa, and that the bacterium killed the alga by direct contact. Daft \& Stewart (1971) noted that Myxobacteriales lysed cyanobacteria within 20 min of contact, and that there were no detectable extracellular products from the bacterium, suggesting that enzymes on the surfaces of the bacteria might be effective in causing lysis. Shilo (1970), Baker \& Herson (1978) and Burnham et al. (1984) suggested that direct contact was ecologically more advantageous for algicidal bacteria, as any chemically mediated substances might easily be diluted by diffusion.

Biological control of cyanobacteria represents a potential short-term measure to reduce or prevent the build-up of nuisance algal populations (Martin et al. 1987). Natural Microcystis blooms decreased rapidly when an increase in algicidal bacteria was previously observed in a hypereutrophic pond. Thus, our laboratory studies support the view that application of Alcaligenes denitrificans into a natural Microcystis bloom may be effective. However, these findings, if extrapolated to natural populations, suggest that, given sufficient lytic bacteria, an algal bloom will not occur unless resistant algae are present.

Acknowledgements. We are grateful to the National Institute for Environmental Studies in Japan for kindly supplying us with microalgal strains for the present study. We are also grateful to Mr M. Kazuaki of the Center for Ecological Research, Kyoto University, for his assistance in identifying the bacterial strains. This study was partly supported by the Japanese Ministry of Education, Science and Culture, Grant in Aid for Creative Basic Research (09 NP1501), 'An integrated study on biodiversity conservation under global change and bio-inventory management system'.

\section{LITERATURE CITED}

Adams MH (1959) Bacteriophage. Inter-Science Publishers, New York, p 450-451

Baker KH, Herson DS (1978) Interactions between the diatom Thallasiosira pseudonanna and an associated Pseudomonad in a mariculture system. Appl Environ Microbiol 35:791-796

Burnham JC, Collart SA, Highison BW (1981) Entrapment and lysis of the cyanobacterium Phormidium luridum by aqueous colonies of Myхососcus xanthus PCo2. Arch Microbiol 129:285-294

Burnham JC, Collart SA, Daft MJ (1984) Myxococcal predation of the cyanobacterium Phormidium luridum in aqueous environments. Arch Microbiol 137:220-225

Carmichael WW, Tones CLA, Mahmood NA, Theiss WC (1985) Algal toxins and water-based diseases. CPC Crit Rev Environ Control 15:275-283

Daft MJ, Stewart WDP (1971) Bacterial pathogens of freshwa- 
ter blue green algae. New Phytol 70:819-829

Day AG, Withers SG (1985) The purification and characterization of a $\beta$-glucosidase from Alcaligenes faecalis. Biochem Cell Biol 64:914-922

Fallon RD, Brock TD (1979) Lytic organisms and photooxidative effects: influence of blue-green algae (Cyanobacteria) in Lake Mendota, Wisconsin. Appl Environ Microbiol 38: 499-505

Fraleigh PC, Burnham JC (1988) Myxococcal predation on cyanobacterial populations: nutrient effects. Limnol Oceanogr 33:476-483

Fukami K, Yuzawa A, Nishijima T, Hata Y (1992) Isolation and properties of a bacterium inhibiting the growth of Gymnodinium nagasakiense. Nippon Suisan Gakkaishi 58: 1073-1077

Fukami K, Sakaguchi K, Kanou M, Nishijima T (1996) Effect of bacterial assemblage on the succession of the blooming phytoplankton from Skeletonema costatum to Heterosigma akashiwo. In: Yasumoto TY, Oshima Y, Fukuyo Y (eds) Harmful and toxic algal blooms. Intergovernmental Oceanographic Commission of UNESCO, Paris, p 335-338

Furuki K, Kobayashi M (1991) Interaction between Chattonella and bacteria and prevention of this red tide. Mar Pollut Bull 23:189-193

Gromov BV, Ivanov OG, Mamkaeva KA, Avilov IV (1972) A flexibacter that lyses blue green algae. Mikrobiologia 41: 1074-1079

Holt GJ, Krieg NR, Sneath PHA, Stanley TT, Williams ST (1994) Bergey's manual of determinative bacteriology, 9th edn. Williams \& Wilkins, Baltimore, MD

Horne JA, Goldman CR (1994) Limnology, 2nd edn. McGrawHill, Inc, New York, p 500-519

Ichimura T (1978) Media for blue-green algae. In: Nishizawa $\mathrm{K}$, Chihara M (eds) Methods in algalogical studies. Kyor-

Editorial responsibility: Bess Ward,

Princeton, New Jersey, USA itsu, Tokyo, p 294-305 (in Japanese)

Mason CF (1996) Biology of fresh water pollution, 3rd edn. Longman, Essex

Manage PM, Kawabata Z, Nakano S (1999) Seasonal changes in densities of cyanophages infectious to $M$. aeruginosa in a hypereutrophic pond. Hydrobiologia 411:211-216

Martin EL, Leach JE, Kuo KJ (1987) Biological regulation of bloom causing blue-green algae. In: Loutit MW, Miles JAR (eds) Microbial ecology. Springer-Verlag, New York, p 62-67

Mitsutani A, Uchida A, Ishida Y (1987) Occurrence of blue green algae and algal lytic bacteria in Lake Biwa. Bull Jpn Soc Microb Ecol 2:21-28

Safferman SR, Morris ME (1964) Control of algae with viruses. J Am Water Works Assoc 56:1217-1224

Shilo M (1970) Lysis of blue-green algae by Myxobacter. J Bact 104:453-461

Sigee DC, Glenn R, Andrews MJ, Bellinger RD, Butlter RD, Epton HAS, Hendry RD (1999) Biological control of cyanobacteria: principles and possibilities. Hydrobiologia 395/396:161-172

Song L, Sano T, Li R, Watanabe MM, Liu Y, Kaya K (1998) Microcystin production of Microcystis viridis (Cyanobacteria) under different culture conditions. Jpn J Phycol 46:19-23

Stewart WDP, Brown RM (1969) Ecological studies on algallysing bacteria in fresh waters. Freshw Biol 5:577-596.

Yamamoto Y, Suzuki K (1990) Distribution and algal-lysing activity of fruiting Myxobacteria in Lake Suwa. J Phycol 26:457-492

Yamamoto Y, Niizuma S, Kuroda N, Sakamoto M (1993) Occurrence of heterotrophic bacteria causing lysis of cyanobacteria in a eutrophic lake. Jpn J Phycol 41: $215-220$

Submitted: March 1, 2000; Accepted: June 5, 2000

Proofs received from author(s): August 7, 2000 